\title{
PENGGUNAAN MEDIA BAHAN DAUR ULANG UNTUK MENINGKATKAN KREATIVITAS MAHASISWA S1 PG-PAUD DI UNIVERSITAS NAHDLATUL ULAMA SURABAYA
}

\author{
Berda Asmara \\ Universitas Nahdlatul Ulama Surabaya \\ Email: asmaraberda@unusa.ac.id
}

\begin{abstract}
Abstrak: Peneliti menggunakan media bahan daur ulang (bahan bekas) yang masih bisa terpakai untuk dijadikan APE (Alat Permainan Edukatif) atau bisa dijadikan hasil karya anak usia dini, sebagai strategi untuk meningkatkan kreativitas terhadap mahasiswa S1 PG-PAUD di UNUSA. yang harus dilakukan oleh mahasiswa sebagai calon pendidik PAUD dengan membuat media pembelajaran yang cocok untuk anak usia dini melalui media bahan daur ulang (bahan bekas). Contoh bahan daur ulang yang bisa dimanfaatkan menjadi APE (Alat Permainan Edukatif) dan hasil karya untuk anak usia dini: botol plastik, gelas plastik, kardus bekas susu formula, kulit jagung, kain perca, baju daur ulang, dan lain sebagainya. Sementara kreativitas merupakan hal yang terpenting khususnya bagi mahasiswa S1 PG-PAUD yang akan menjadi calon guru / pendidik di PAUD. Tujuan dari kreativitas untuk mengembangkan anak dalam hal kemampuan berfikir, berapresiasi, bereksplorasi dan berkreasi. Dalam memanfaatkan bahan daur ulang, mahasiswa S1 PG-PAUD UNUSA belajar mengolah perasaan, kepekaan, intuisi dan imajinasinya. Dengan demikian kreativitas di PAUD menjadi strategis dalam pengembangan kreativitas sebagai calon guru / pendidik dan anak di PAUD. Berdasarkan kerangka pemikiran tersebut, sangat diperlukan penelitian yang ditujukan dalam memanfaatkan media bahan daur ulang untuk meningkatkan kreativitas mahasiswa S1 PG-PAUD di UNUSA. Penelitian ini merupakan penelitian tindakan kelas (PTK), karena penelitian ini dimaksudkan untuk meningkatkan kreativitas mahasiswa S1 PGPAUD di UNUSA. Adanya peningkatan kreativtias mahasiswa S1 PG-PAUD UNUSA dari tiap tingkatan siklus, Hal ini dibuktikan bahwa dengan memanfaatkan media bahan daur ulang dapat meningkatkan kreativitas mahasiswa, dalam pengambilan data. pada siklus I ketuntasan meningkatakan kreativitas mahasiswa S1 PG-PAUD UNUSA sebesar 68\% meningkat di siklus II menjadi 78\%
\end{abstract}

Kata kunci: media bahan daur ulang, kreativitas, Mahasiswa S1 PG-PAUD

\begin{abstract}
Researchers use recycled materials media (used materials) that can still be used to be used as an APE (Educational Game Equipment) or can be used as work of early child, as a strategy to increase the creativity of PG-PAUD undergraduate students at UNUSA. which should be done by students as PAUD educator candidates by making learning media suitable for early childhood through recycled material media (used materials). Examples of recycled materials that can be used as APE (Educational Game Players) and work for early childhood: plastic bottles, plastic cups, ex-formula milk cartons, corn husks, patchwork, recycled clothes, and so on. While creativity is paramount especially for PG-PAUD SI students who will become prospective teachers / educators in PAUD. The purpose of creativity to develop children in terms of ability to think, appreciate, explore and be creative. In utilizing recycled materials, undergraduate students of PG-PAUD UNUSA learn to cultivate feelings, sensitivity, intuition and imagination. Thus,
\end{abstract}


creativity in early childhood becomes strategic in the development of creativity as a teacher / educator and child in PAUD. Based on this framework, it is necessary research aimed at utilizing recycled materials media to improve the creativity of $P G$ $P A U D$ undergraduate students at UNUSA. This research is a class action research (PTK), because this research is intended to improve the creativity of PG-PAUD undergraduate students at UNUSA. There is increasing creativity of PG-PAUD UNESA S1 students from each cycle level, it is proven that by utilizing recycled material media can improve student creativity. in the data retrieval. in the cycle I mastery increases the creativity of undergraduate students PG-PAUD UNUSA by $68 \%$ increase in cycle II to $78 \%$

Keyword: media recycling materials, creativity, Student S1 PG-PAUD

\section{PENDAHULUAN}

Media adalah segala sesuatu yang dapat digunakan untuk menyalurkan pesan dari guru kepada anak sehingga dapat merangsang pikiran, perasaan, perhatian dan minat serta perhatian anak (Arsyad, 2013).

Azhar Arsyad (2009:67) berpendapat bahwa Pembelajaran yang efektif memerlukan perencanaan yang baik. Media yang akan digunakan dalam proses pembelajaran itu juga memerlukan perencanaan yang baik. Meskipun demikian, kenyataan dilapangan menunjukkan bahwa seorang guru memilih salah satu media dalam kegiatannya di kelas atas dasar pertimbangan antara lain (a) ia merasa sudah akrab dengan media yang diterimanya, (b) ia merasa bahwa media yang dipilihnya dapat menggambarkan dengan lebih baik daripada dirinya sendiri, (c) media yang dipilihnya dapat menarik minat dan perhatian siswa, serta menuntunnya pada penyajian yang lebih terstruktur dan terorganisasi.

Dampak perkembangan Ipteks pada proses pembelajaran antara lain banyaknya sumber dan media belajar seperti buku teks, modul, lembar kegiatan, film, video, televisi, radio dan lain sebagainya. Pendidik yang profesional di tuntut mampu memilih dan menggunakan berbagai media yang dapat menunjang pembelajarannya. Karena proses pembelajaran merupakan proses komunikasi yang berlangsung dalam suatu sistem, maka peran media pembelajaran sangat penting sebagai pembawa informasi dari sumber (guru) menuju penerima (anak). Seorang anak akan lebih mudah mempelajari hal yang konkrit dari pada abstrak (Arsyad, 2013)

Pendidikan dapat terjadi di mana saja, seperti di rumah, di sekolah dan juga di lingkungan masyarakat. Masingmasing tempat memiliki pengaruh yang besar terhadap pendidikan terlebih pada tumbuh kembang anak usia dini. Seperti halnya pendidikan di sekolah formal yang mempunyai peranan yang sangat penting dalam mencetak dan memberikan ilmu adalah guru (pendidik). Kemampuan intelektual dan kreativitas guru sangat berpengaruh terhadap pendidikan yang diterima anak selama di sekolah

Alasan peneliti menggunakan media bahan daur ulang (bahan bekas) yang 
masih bisa terpakai untuk dijadikan APE (Alat Permainan Edukatif) atau bisa dijadikan hasil karya anak usia dini, sebagai strategi untuk meningkatkan kreativitas terhadap mahasiswa S1 PGPAUD di UNUSA. Yang harus dilakukan oleh calon pendidik PAUD di Kota Surabaya dengan membuat media pembelajaran yang cocok untuk anak usia dini melalui media bahan daur ulang (bahan bekas). Contoh bahan daur ulang yang bisa dimanfaatkan menjadi APE (Alat Permainan Edukatif) dan hasil karya untuk anak usia dini: botol plastik, gelas plastik, kardus bekas susu formula, kulit jagung, kain perca, baju daur ulang, dan lain sebagainya.

Permasalahan inilah yang akan diungkap secara penuh khususnya untuk mahasiswa S1 PG-PAUD di UNUSA yang nantinya akan menjadi calon guru/pendidik PAUD. Sebagai bukti masih banyak memandang sebelah mata tentang kreativitas, terutama untuk guru PAUD diutamakan adalah guru yang kreatif, inovatif, dan terampil dalam pembelajaran terutama dalam memilih dan memberikan media pembelajaran yang cocok untuk anak usia dini dengan memanfaatkan media dari bahan daur ulang sehingga tidak perlu membeli APE

Kreativitas melalui media bahan daur ulang merupakan salah satu usaha untuk meningkatkan kreativitas mahasiswa S1 PG-PAUD di UNUSA beserta dengan anak didiknya. Dalam pelaksanaannya adalah pendidik / mahasiswa PAUD membuat media pembelajaran yang cocok dengan anak usia dini dengan memanfaatkan media bahan daur ulang (bahan bekas), sampai sejauh ini kreativitas yang ditunjukkan mahasiswa
S1 PG-PAUD di UNUSA pada mata kuliah media pembelajaran AUD belum semua menunjukkan kreativitasnya hanya $20 \%$ saja yang sudah terlihat kreativitasnya terlebih dengan memanfaatkan bahan daur ulang (bahan bekas). Memanfaatkan bahan daur ulang oleh mahasiswa S1 PG-PAUD di UNUSA masih terasa jauh dari keterjangkauan.

\section{a. Rumusan Masalah}

Memperhatikan latar belakang tersebut maka penelitian ini dapat dirumuskan suatu permasalahan sebagai berikut : "Apakah Penggunaan Media Bahan Daur Ulang dapat meningkatkan kreativitas mahasiswa S1 PG-PAUD di UNUSA?

\section{b. Tujuan Penelitian}

Berdasarkan latar belakang dan rumusan masalah yang dikemukakan di atas, maka penelitian ini bertujuan : "Untuk mengetahui apakah penggunaan media bahan daur ulang dapat meningkatkan kreativitas mahasiswa S1 PG-PAUD

\section{c. Manfaat Penelitian}

Penelitian ini sangat penting untuk mahaiswa, dosen maupun Universitas yang lain. Adapun manfaat yang bisa diambil dalam penelitian ini adalah:

\section{1) Untuk Anak}

Meningkatkan kreativitas mahasiswa dalam memanfaatkan media bahan daur ulang untuk meningkatkan kreativitas mahasiswa dapat tercapai. Selain itu, mempersiapkan mahasiswa untuk menjadi seorang pendidik/guru terutama pada Lembaga Pendidikan Anak Usia Dini (PAUD) dimana pada prinsip PAUD 
yaitu bermain sambil belajar dan belajar seraya bermain.

2) Untuk Dosen

Menjadi salah satu alternatif untuk meningkatkan kreativitas mahasiswa S1 PG-PAUD yaitu dengan memanfaatkan media bahan daur ulang sehingga bisa dijadikan Alat Permainan Edukatif yang cocok untuk AUD sesuai dengan usia anak serta meningkatkan kualitas pembelajaran agar lebih baik.

3) Untuk Universitas

Sebagai masukan dalam upaya meningkatkan kreativitas mahasiswa melalui media bahan daur ulang. Selain itu, membantu mengatasi permasalahan yang terdapat di Universitas agar lebih baik.

\section{KAJIAN PUSTAKA}

\section{a. Media Pembelajaran}

Kata media berasal dari bahasa latin medius yang secara harfiah berarti "tengah", "perantara" atau "pengantar". Media adalah perantara atau pengantar pesan dari pengirim kepada penerima pesan. Arsyad (2013:3) mengatakan bahwa media apabila dipahami secara garis besar adalah manusia, materi, atau kejadian yang membangun kondisi yang membuat siswa mampu memperoleh pengetahuan Proses belajar mengajar hakikatnya adalah proses komunikasi, guru berperan sebagai pengantar pesan dan siswa sebagai penerima pesan. Pesan yang dikirimkan oleh guru berupa isi atau ajaran yang dikembangkan dalam simbolsimbol komunikasi baik verbal (kata-kata dan tulisan) maupun nonverbal. Proses ini disebut encoding. Penafsiran simbolsimbol komunikasi tersebut oleh anak disebut decoding.
Pembelajaran dengan menggunakan media akan memberikan gairah dalam belajar, anak berkembang menurut minat dan kecepatannya, interaksi langsung dengan lingkunagan, memberikan rangsangan dan pengalaman yang menimbulkan persepsi akan sebuah konsep yang sama (Trianto, 2009:235) Teknologi pembelajaran secara konseptual didefinisikan sebagai sebuah teori dan praktek dalam mendesain, pengembangan, pemanfaatan, pengelolaan, dan evaluasi proses, serta sumber belajar (Richey, 1994). Dari definisi tersebut mengandung empat komponen, yaitu: (1) teori dan praktek, (2) desain, (3) proses dan sumber, (4) sebagai keperluan belajar Pembelajaran melaluli audio visual perkembangan keras selam proses pembelajaran, seperti proyektor film, tape recorder, dan proyektor visual lebar. Pengajaran dengan audio visual adalah produksi dan penggunaan materi penyerapannya melalui pandangan dan pendengaran serta tidak seluruhnya tergantung pada pemahaman kata atau simbol yang serupa. Adapun prinsip pemilihan media (Aryad, 2013) antara lain:

1) Motivasi

Harus ada kebutuhan, minat atau keinginan untuk belajar dari pihak anak sebelum meminta perhatiannya untuk mengerjakan tugas dan latihan.

2) Perbedaan Individual Anak belajar dengan cara dan tingkat kecepatan yang berbeda-beda.

3) Tujuan Pembelajaran

Jika anak diberitahukan apa yang diharapkan mereka pelajari melalui media pembelajaran itu, kesempatan 
untuk berhasil dalam pembelajaran semakin besar.

4) Organisasi Isi

Pembelajaran akan lebih mudah jika isi dan prosedur atau keterampilan fisik yang akan dipelajari diatur dan diorganisasikan kedalam urut-urutan yang bermakna.

5) Persiapan Sebelum Belajar

Anak sebaiknya telah menguasai secara baik pelajaran dasar atau memiliki pengalaman yang diperlukan secara memadai yang mungkin merupakan prasyarat untuk penggunaan media yang sukses.

6) Emosi

Pembelajaran yang melibatkan emosi dan perasaan pribadi serta kecakapan amat berpengaruh dan bertahan.

7) Partisipasi

Agar pembelajaran berlangsung dengan baik, seorang siswa harus menginternalisasi informasi, tidak sekadar diberitahukan kepadanya.

8) Umpan Balik

Hasil belajar dapat meningkat apabila secara berkala anak diinformasikan kemajuan belajarnya.

9) Penguatan (Reinformance)

Apabila siswa berhasil belajar, ia didorong oleh keberhasilan amat bermanfaat, dapat membangun kepercayaan diri, dan secara positif mempengaruhi perilaku di masamasa yang akan datang.

10) Latihan dan Pengulangan

Sesuatu hal baru jarang sekali dapat dipelajari secara efektif hanya dengan sekali jalan.

\section{1) Penerapan}

Hasil belajar yang diinginkan adalah meningkatkan kemampuan seseorang untuk menerapkan atau mentransfer hasil belajar pada masalah atau situasi baru

\section{b. Kreativitas}

Adapun proses kreatif hanya akan terjadi jika dibangkitkan melalui masalah yang memacu pada lima macam perilaku kreatif, sebagaimana yang dipaparkan oleh Parnes (dalam Nursito: 2000) sebagai berikut:

1) Fluency (Kelancaran), yaitu kemampuan mengemukakan ide yang serupa untuk memecahkan masalah.

2) Flexibility (Keluwesan), yaitu kemampuan untuk menghasilkan berbagai macam ide guna memecahkan suatu masalah di luar kategori yang biasa.

3) Originality (keaslian), yaitu kemampuan memberikan respons yang unik atau luar biasa

4) Elaboration (keterperincian), yaitu kemampuan menyatakan pengarahan ide secara terperinci untuk mewujudkan ide menjadi kenyataan.

5) Sensitivity (kepekaan), yaitu kepekaan menangkap dan menghasilkan masalah sebagai tanggapan terhadap suatu situasi.

\section{c. Hubungan Kreativitas dan Kecerdasan Manusia}

Kreativitas merupakan salah satu ciri perilaku yang menunjukkan perilaku inteligent (cerdas), namun kreativitas dan inteligensi tidak selalu menunjukkan korelasi yang memuaskan. Sebab IQ (Inteligence Quotient) yang rendah 
memang selalui diikuti oleh tingkat kreativitas yang rendah pula, namun skor IQ yang tinggi ternyata tidak selalu dibarengi oleh tingkat kreatvitas yang tinggi pula. Kreativitas akan muncul pada individu yang memiliki motivasi tinggi, rasa ingin tahu, dan imajinasi. Seseorang yang kreatif akan selalu mencari dan menemukan jawaban, dengan kata lain mereka senang memcahkan masalah

\section{METODE PENELITIAN \\ a. Pendekatan Penelitian}

Langkah-langkah setiap siklus dalam penelitian ini, dapat dibagi menjadi empat tahap, yaitu :

\section{Siklus I}

1) Rancangan/rencana awal

Implementasi siklus pada perencanaan adalah mepersiapkan materi yang sesuai dengan RPS dan RPP, dan mempersiapkan kegiatan pemanfaatan media bahan daur ulang dan alat-alat yang diperlukan lainnya.

\section{2) Pelaksanaan}

Sebagaimana dikemukakan (dalam Suharjono, 2008: 39). Pada tahap Implementasi dilakukan penggelaran skenario kerja tindakan perbaikan dan prosedur tindakan yang diterapkan.

\section{3) Pengamatan}

Data yang dikumpulkan selama tindakan berlangsung kemudian dianalisis. Berdasarkan hasil analisis ini peneliti melakukan pengamatan, yaitu dicoba merenungkan atau mengingat dan menghubunghubungkan kejadian dalam interaksi kelas, mengapa terjadi, dan bagaimana hasilnya. Hasil pengamatan akan terlihat tingkat keberhasilan dan kegagalan yang dicapai dalam tindakan perbaikan.

\section{4) Refleksi}

Hasil refleksi ini merupakan masukan peneliti dalam merencanakan dan melaksanakan tindakan perbaikan berikutnya. Refleksi dapat dilakukan peneliti bersama teman sejawat, bertujuan untuk mengkaji dan menganalisis pelaksanaan tindakan pada siklus 1 dengan jalan mengidentifikasi baik kemajuan-kemajuan yang telah diperoleh maupun kekurangankekurangan atau hambatan-hambatan yang masih dihadapi, kemudian, setelah mendapat persetujuan dari kedua belah pihak refleksi tersebut digunakan untuk memperbaiki rencana tindakan pada siklus selanjutnya. Penelitian awal dilakukan untuk menganalisis kreativitas mahasiswa S1 PG-PAUD dalam pada mata kuliah media pembelajaran AUD di Universitas Nahdlatul Ulama Surabaya (UNUSA). Berdasarkan hasil analisis yang telah dilakukan, ditemukan permasalahan yang berkaitan dengan kreativitas Mahasiswa S1 PG-PAUD yang kurang maksimal. Oleh karena itu, akan dilakukan pemanfaatan media bahan daur ulang untuk meningkatkan kreativitas mahasiswa PAUD pada mata kuliah media pembelajaran AUD.

\section{b. Rancangan Penelitian}

Penelitian ini direncanakan akan dilaksanakan 1 Bulan. Adapun rincian 
kegiatan yang akan dilakukan adalah sebagai berikut.

1) Mengidentifikasi kreativitas mahasiswa S1 PG-PAUD dengan menggunakan media bahan daur ulang.

2) Observasi terhadap kreativitas mahasiswa S1 PG-PAUD dalam membuat media pembelajaran dari bahan daur ulang yang cocok untuk anak usia dini, meliputi: kurikulum, materi ajar, pendekatan, durasi waktu kegiatan, setting pengorganisasian anak didik dikelas, sarana dan prasarana yang mendukung pembelajaran, aktifitas anak didik di kelas dan strategi serta pendekatan yang digunakan dalam memanfaatkan media bahan daur ulang.

3) Mengidentifikasi persepsi mahasiswa S1 PG-PAUD terhadap kreativitas dalam menggunakan media bahan daur ulang pada mata kuliah media pembelajaran AUD.

4) Analisis temu sebagai dasar dan bahan pertimbangan dalam memanfaatkan media bahan daur ulang untuk meningkatkan kreativitas mahasiswa S1 PG-PAUD pada mata kuliah media pembelajaran AUD.

5) Memanfaatkan media pembelajaran dari bahan daur ulang untuk meningkatkan kreativitas mahasiswa S1 PG-PAUD di UNUSA.

6) Memilih dan menetapkan ruang lingkup materi, tingkatan kompleksitas materi, pendekatan aspek kreativitas yang dikembangkan dalam meningkatkan kreativitas mahasiswa S1 PG-PAUD di UNUSA.
Pembuatan media bahan daur ulang untuk meningkatkan kreativitas mahasiswa S1 PG-PAUD di UNUSA

\section{c. Instrumen Pengumpulan Data}

Instrumen pengumpulan data yang digunakan dalam penelitian ini menggunakan pedoman observasi dan dokumentas. Pedoman ini untuk mengetahui kebutuhan pengguna. observasi dilakukan di dalam kelas (ruangan) dalam bentuk pemberian tugastugas kepada mahasiswa S1 PG-PAUD . Sedangkan, dokumentasi dilakukan Mahasiswa S1 PG-PAUD semester III kelas A (Anak Reguler) yang ada di UNUSA . Mahasiswa S1 PG-PAUD di UNUSA terbagi menjadi dua yaitu: Mahasiswa Reguler dan Mahasiswa Bunda PAUD. Mahasiswa Reguler merupakan mahasiwa fresh graduate dimana semua mahasiswa lulusan SMA dan belum bekerja atau belum manjadi guru / pendidik PAUD sedangkan Mahasiswa Bunda PAUD adalah mahasiswa yang sudah bekerja menjadi guru / pendidik di Lembaga PAUD (PPT, TPA, dan TK/RA)

\section{d. Teknik Pengumpulan Data}

Analisa data ini merupakan lanjutan dari kegiatan pengumpulan data. Untuk itu, seorang peneliti perlu memahami teknik analisis data yang tepat agar manfaat penelitiannya memiliki nilai yang tinggi. Beberapa data yang diperoleh dalam penelitian ini adalah data hasil observasi aktivitas mahasiswa S1 PG-PAUD di UNUSA pada mata kuliah media pembelajaran AUD dengan memanfaatkan media bahan daur ulang. Data yang sudah terkumpul kemudian 
dianalisis. Untuk mengetahui data hasil observasi dan data hasil tes, maka digunakan rumus sebagai berikut:

$$
P=\frac{A}{N}_{100 \%}
$$

Keterangan:

$\mathrm{P}=$ Angka Persentase

$\mathrm{A}=$ Kemampuan yang dicapai

$\mathrm{N}$ = Jumlah Kemampuan Maksimal

Sudijono (dalam Wahyuningtyas, 2012:41)

\section{e. Standart Keberhasilan}

Data yang diperoleh di analisis menggunakan patokan standar keberhasilan. Mahasiswa dikatakan berhasil apabila telah mencapai standar prosentase $\geq 75 \%$ dari jumlah mahasiswa keseluruhan dan mampu meningkatkan kreativitas dalam memanfaatkan media bahan daur ulang pada mata kuliah metode pengembangan kognitif dan kreativitas AUD

\section{HASIL PENELITIAN DAN PEMBAHASAN}

Penelitian ini merupakan penelitian tindakan kelas (PTK), karena penelitian ini dimaksudkan untuk meningkatkan kreativitas mahasiswa S1 PG-PAUD di UNUSA, dimana peneliti terlibat langsung dalam proses pemanfaatan media bahan daur ulang yang dijadikan media pembelajaran untuk anak usia dini (anak didi). Dalam penelitian ini, peneliti meneliti tentang penggunaan media bahan daur ulang untuk meningkatkan kreativitas mahasiswa S1 PG-PAUD di
UNUSA. Dari penelitian ini dapat dideskripsikan secara rinci hasil penelitian dan pembahasan sebagai berikut

\section{a. Hasil Penelitian}

Penelitian tindakan kelas ini dilakukan untuk meningkatkan kreativitas mahasiswa S1 PG-PAUD di UNUSA melalui pemanfaatan media bahan daur ulang untuk dijadikan media pembelajaran berupa APE (Alat Permainan Edukatif) yang cocok untuk anak usia dini. Pertemuan pada siklus I dilakukan sebanyak dua kali pertemuan yaitu pertemuan pertama pada tanggal 03 Mei 2018 dan pertemuan kedua pada tanggal 10 Mei 2018 antara pukul 07.0009.30 WIB. Sedangkan pengamatan dalam pengisian lembar observasi hanya dilakukan pada pertemuan kedua yaitu tanggal 10 Mei 2018. Peningkatan kreativitas diikuti sebanyak 27 mahasiswa S1 PG-PAUD di UNUSA. Pada proses kali ini yang dilakukan terlebih dahulu adalah memilih dan menentukan jenis bahan daur ulang apa yang akan digunakan dalam pembuatan APE yang cocok untuk anak usia dini.

a. Perencanaan

1). Siklus I Pertemuan Pertama

a) Menyusun Rencana Pelaksanaan Pembelajaran.

b) Menyusun jenis APE yang akan dibuat dari bahan daur ulang.

c) Menyusun jenis bahan daur ulang yang akan di kelola.

2) Siklus I Pertemuan Kedua

Pada tahap ini, peneliti memberikan pemecahan terhadap kendala-kendala yang ditemukan peneliti pada waktu proses pembuatan media bahan daur 
ulang pada pertemuan pertama. Dari hasil pengamatan yang ada pada pertemuan pertamam selanjutnya peneliti melakukan perencanaan tindakan selanjutnya dengan langkah-langkah sebagai berikut:

a) Menyusun Rencana Pelaksanaan Pembelajaran (RPP).

b) Menentukan jenis APE yang akan dibuat dari bahan daur ulang.

c) Menentukan jenis bahan daur ulang yang akan di kelola.

b. Pelaksanaan

Pelaksanaan tindakan siklus I ini mengacu pada langkah-langkah pembelajaran yang tertulis dalam RPP dan akan dilaksanakan oleh mahasiswa S1 PG-PAUD di UNUSA untuk meningkatkan kreativitas dalam memanfaatkan bahan daur ulang yang akan dijadikan media pembelajaran berupa APE.

Adapun pelaksanaan kedua pertemuan adalah sebagai berikut:

1). Pertemuan Pertama

a) Peneliti membahas tentang materi hari ini sesuai dengan RPP

b) Peneliti mengajak mahasiswa berdiskusi dan tanya jawab tentang materi yang sudah disampaikan

2). Pertemuan Kedua

a) Setelah mahasiswa mengetahui materi yang sudah dijelaskan oleh peneliti (dosen), guru akan mengenalkan media pembelajaran (APE) yang sudah dibuat dari bahan daur ulang

b) Peneliti memberi kesempatan kepada mahasiswa untuk menggunakan media bahan daur ulang tersebut yang sesuai dengan tema dan RPP. c) c). Hasil Pengamatan atau Observasi Hasil Peningkatan Kreativitas mahasiswa S1 PG-PAUD di UNUSA, Proses pembuatan media pembelajaran dari bahan daur ulang diawali dengan peneliti mengajak mahasiswa untuk berdiskusi tentang APE yang disukai oleh anak usia dini (anak didik) yang cocok dengan usianya. Dari hasil analisis pada tahap siklus I, diperoleh data yang menunjukkan bahwa kreativitas mahasiswa S1 PG-PAUD UNUSA dalam memanfaatkan media bahan daur ulang dijadikan media pembelajaran yang berupa APE (Alat Permainan Edukatif) yang cocok untuk anak usia dini di pada mata kuliah metode pengembangan kognitif dan kreativitas mencapai 68\%. Namun hasil ini belum mencapai standar persentasi minimal yaitu $\geq 75 \%$ dari jumlah mahasiswa S1 PG-PAUD UNUSA.

d) Refleksi

Pada siklus I telah menunjukkan adanya suatu peningkatan dibandingkan pada waktu pra siklus. Namun hasil pada siklus I masih belum memuaskan dan belum sesuai dengan harapan peneliti. Hal ini karena standar persentase yang masih $\geq 75 \%$ yaitu persentase ketuntasan yang diraih oleh mahasiswa S1 PGPAUD di UNUSA adalah sebesar $68 \%$.

e) Berikut kendala yang muncul pada siklus I antara lain:

a. Beberapa mahasiswa S1 PG-PAUD di UNUSA belum mampu memanfaatkan bahan daur ulang untuk media pembelajaran anak usia dini, 
bahan yang diperoleh hasil dari bahan layak pakai atau membeli di toko.

2. Kreativitas beberapa mahasiswa $\mathrm{S} 1$ PG-PAUD di UNUSA yang lainnya dalam memanfaatkan media bahan daur ulang dirasa sudah bagus namun kurang menarik bagi anak didik untuk dijadikan media pembelajaran yang cocok untuk anak usia dini, sehingga perlu peningkatan lagi, seperti diberi warna yang menarik, penggunaannya mudah agar anak uisa dini lebih bersemangat dalam kegiatan pembelajaran sehari-hari yang disesuaikan tema di PAUD. Dengan dua kendala tersebut diatas maka sebagai peneliti berupaya memperbaiki kekurangan-kekurangan yang ada pada siklus I tersebut dan terus berupaya untuk meningkatkan kreativitas mahasiswa S1 PG-PAUD di UNUSA.

3. Pelaksanaan Tindakan Siklus II Pelaksanaan tindakan siklus II ini dimaksudkan utnuk mengatasi dua kendala yang muncul pada siklus I dan memperbaiki masalah yang terdapat dalam siklus I dapat teratasi. Pertemuan pada siklus II dilakukan sebanyak dua kali pertemuan yaitu pertemuan pertama pada tanggal 17 Mei 2018 dan pertemuan kedua pada tanggal 24 Mei 2018 antara pukul 07.00-09.30 WIB. Sedangkan pengamatan dalam pengisian lembar observasi hanya dilakukan pada pertemuan kedua yaitu tanggal $24 \mathrm{Mei}$ 2018.
Adapun pelaksanaan siklus II dapat diuraikan sebagai berikut:

a. Perencanaan

1). Siklus I Pertemuan Pertama

a) Menyusun Rencana Pelaksanaan Pembelajaran

b) Menetapkan jenis APE yang sudah dibuat dari bahan daur ulang

c) Menetapkan jenis bahan daur ulang yang akan di kelola.

\section{2) Siklus II Pertemuan Kedua}

Pada tahap ini, peneliti memberikan pemecahan terhadap dua kendala yang ditemukan peneliti pada waktu proses pembuatan media bahan daur ulang pada pertemuan pertama. Dari hasil pengamatan yang ada pada pertemuan pertama selanjutnya peneliti melakukan perencanaan tindakan selanjutnya dengan langkah-langkah sebagai berikut:

a) Menyusun Rencana Pelaksanaan Pembelajaran (RPP)

b) Mendemonstrasikan APE yang sudah dibuat dari bahan daur ulang

b. Pelaksanaan

Pelaksanaan tindakan siklus I ini mengacu pada langkah-langkah pembelajaran yang tertulis dalam RPP dan akan dilaksanakan oleh mahasiswa S1 PG-PAUD di UNUSA untuk meningkatkan kreativitas dalam memanfaatkan bahan daur ulang yang akan dijadikan media pembelajaran berupa APE.

Adapun pelaksanaan kedua pertemuan adalah sebagai berikut:

1). Pertemuan Pertama

a).Peneliti memberikan materi hari ini sesuai dengan RPP 
b).Peneliti mengajak mahasiswa berdiskusi dan tanya jawab tentang materi yang sudah dijelaskan.

2). Pertemuan Kedua

a) Setelah mahasiswa mengetahui tema yang sudah dijelaskan peneliti (dosen), peneliti akan mengenalkan media pembelajaran (APE) yang sudah dibuat dari bahan daur ulang

b) Peneliti memberi kesempatan kepada mahasiswa untuk menggunakan media bahan daur ulang tersebut yang sesuai dengan materi dan berwarma-warni yang menarik untuk anak usia dini dan sesuai dengan RPP.

c) Hasil Pengamatan atau Observasi Hasil Peningkatan Kreativitas mahasiswa S1 PG-PAUD di UNUSA. Proses pembuatan media pembelajaran dari bahan daur ulang diawali dengan peneliti mengajak mahasiswa untuk berdiskusi tentang APE yang disudah dibuat oleh mahasiswa S1 PG-PAUD di UNUSA dengan sedemikian menarik, dengan warna-warni dan cocok di aplikasikan pada anak usia dini sesuai dengan materi dan RPP.

Dari hasil analisis pada tahap siklus II, diperoleh data yang menunjukkan bahwa mahasiswa S1 PG-PAUD UNUSA dalam memanfaatkan bahan daur ulang dijadikan media pembelajaran yang berupa APE (Alat Permainan Edukatif) yang cocok untuk anak usia dini pada mata kuliah metode pengembangan kognitif dan kreativitas mencapai $78 \%$ dari semula yang hanya $65 \%$ dari hasil siklus I. Hasil tersebut sudah mencapai standar persentase $\geq 75 \%$ dari jumlah mahasiswa S1 PG-PAUD UNUSA.

d) Refleksi

e) Berdasarkan hasil observasi terhadap peningkatan kreativitas mahasiswa $\mathrm{S} 1$ PG-PAUD UNUSA selama pelaksanaan pada siklus II menunjukkan bahwa adanya suatu peningkatan. Hal ini dapat dilihat dari hasil persentase ketuntasan pada siklus II mencapai 78\%. Dari uraian tersebut, maka proses peingkatan kreativitas mahasiswa S1 PG-PAUD UNUSA dalam siklus II termasuk dalam kriteria standar persentase. Hal ini menunjukkan bahwa pelaksanaan siklus II sudah bisa dikatakan berhasil dan dirasa cukup mewakili dari tujuan yang telah direncanakan yaitu untuk mengetahui apakah pemanfaatan media bahan daur ulang dapat meningkatkan kreativitas mahasiswa S1 PG-PAUD UNUSA. Dengan demikian penelitian tindakan kelas dalam penelitian ini dapat dilakukan sampai pada siklus II.

\section{PEMBAHASAN}

Dari hasil siklus I dan siklus II terjadi peningkatan kreativitas mahasiswa S1 PG-PAUD UNUSA yang signifikan. Selain itu dilihat dari hasil peningkatan kreativitas dengan menggunakan media bahan daur ulang yang dibuat oleh mahasiswa S1 PG-PAUD UNUSA, ternyata banyak anak yang senang dalam menggunakannnya, hal ini dapat dilihat dari hasil peningkatan kreativitas mahasiswa S1 PG-PAUD UNUSA selama pembuatan dan mengaplikasikan terhadap anak didik yang meningkat dari 
$68 \%$ pada siklus I menjadi $78 \%$ pada siklus II. Berdasarkan hasil penelitian ini diketahui bahwa pemanfaatan media bahan daur ulang telah mampu membawa perubahan pada mahasiswa S1 PGPAUD UNUSA dalam meningkatkan kreativitasnya, meskipun masih terdapat kekurangan/kelemahan dalam pembuatan dan penerapannya. Kreativitas dan inovasi guru sangat dibutuhkan untuk memperbaiki kelemahan-kelemahan yang terjadi, baik yang dialami mahasiswa S1 PG-PAUD UNUSA. Perbaikan langkah-langkah tindakah peningkatan kreativitas yang dilakukan oleh mahasiswa S1 PG-PAUD UNUSA, berpengaruh sangat signifikan pada kinerja anak usia dini.

Proses pembuatan media pembelajaran dari bahan daur ulang dirasa berhasil dalam meningkatkan kreativitas mahasiswa S1 PG-PAUD UNUSA. Pada siklus I ketuntasan meningkatakan kreativitas mahasiswa $\mathrm{S} 1$ PG-PAUD UNUSA sebesar $68 \%$ meningkat di siklus II menjadi $78 \%$ Adanya peningkatan kreativtias mahasiswa S1 PG-PAUD UNUSA dari tiap tingkatan siklus, hal ini karena dengan memanfaatkan media bahan daur ulang dijadikan media pembelajaran berupa APE yang cocok untuk anak usia dini dan mahasiswa sangat senang dalam mengimplementasikan media pembelajaran dari bahan daur ulang tersebut, terutama dalam memanfaatkan media bahan daur ulang

\section{SIMPULAN}

Berdasarkan hasil penelitian dan pembahasan pada bab sebelumnya yaitu bab $\mathrm{V}$ yang menunjukkan adanya peningkatan kreativitas mahasiswa $\mathrm{S} 1$ PG-PAUD UNUSA mengalami peningkatan setiap siklusnya. Hal ini dapat dipaparkan oleh peneliti yakni melalui media bahan daur ulang dapat meningkatkan kreativitas mahasiswa S1 PG-PAUD UNUSA. Hal ini dapat ditunjukkan dengan pencapaian pada siklus I sebesar $68 \%$ dan meningkat pada siklus II sebesari $78 \%$,

Dari uraian tersebut diatas menunjukkan bahwa hasil peningkatan kreativitas mahasiswa S1 PG-PAUD UNUSA sudah mencapai standar persentase $\geq 75 \%$ dari keseluruhan mahasiswa S1 PG-PAUD UNUSA. Sehingga dapat ditarik suatu kesimpulan bahwa melalui penggunaan media bahan daur ulang dapat meningkatkan kreativitas mahasiswa S1 PG-PAUD UNUSA

\section{SARAN}

\section{a. Bagi Univesitas}

1) Untuk Lembaga pendidikan anak usia dini (PAUD) dapat menggunakan media bahan daur ulang yang berupa APE untuk meningkatakn kreativitas mahasiswa S1 PG-PAUD UNUSA.

2) mahasiswa $S 1$ PG-PAUD UNUSA dapat meningkatkan kreativitasnya berupa APE yang sangat menarik dan cocok digunakan pada anak usia dini sehari-hari di Lembaga PAUD dalam menggunakan media pembelajaran dengan memanfaatkan media bahan daur ulang. 


\section{b. Bagi Peneliti Lain}

1) Penelitian ini dapat dijadikan sebagai acuan bagi peneliti berikutnya khususnya pada peningkatan kreativitas mahasiswa S1 PG-PAUD UNUSA dalam memanfaatkan media bahan daur ulang menjadi alat permainan edukatif (APE) untuk anak usia dini yang menarik.

2) Fokus pada subyek penelitian mahasiswa S1 PG-PAUD UNUSA diharapkan dapat diperluas dengan subyek yang lebih besar lagi dan latar belakang serta permasalahan yang berbeda.

\section{DAFTAR PUSTAKA}

Aqib, Zainal. 2009. Belajar dan Pembelajaran di Taman KanakKanak. Bandung: Yrama Widya.

Arsyad, Azhar. 2009. Media Pembelajaran. Jakarta: Rajawali Pers.

Departemen Pendidikan Nasional, 2007. Pedoman Pembelajaran Kognitif di Taman Kanak-

Kanak. Jakarta: Dirjen Manajemen Dikdasmen, Direktoral Pembinaan TK dan SD.

Depdiknas. 2008. Pengembangan Model Pembelajaran di Taman KanakKanak. Direktorat Pembinaan Taman Kanak-Kanak dan Sekolah Dasar.

Lowenfeld, V. dan Brittain, W.L. 1982.Creative and Mental Growth. New York: Macmillan Publishing Co.

Sudjana, A. R. (1992). Media Pengajaran. Bandung: Sinar Baru.
Sudono, Anggani. 2000. Sumber Belajar dan Alat Permainan untuk Pendidikan Anak Usia Dini. Jakarta: PT Grasindo.

Suharsimi, Arikunto. 2010. Prosedur Penelitian - Suatu Pendekatan Praktik. Jakarta: Rineka Cipta.

Sujiono, Nurani, Yuliani \& Sujiono, Bambang. 2010. Bermain Kreatif Berbaris Kecerdasan Jamak. Jakarta: PT. Indeks.

Susanto, Ahmad. 2011. Pekembangan Anak Usia Dini. Jakarta: Kencana Prenada Group. 